\title{
Efektifitas Community Education System (CUBES) dengan Pendekatan Peer Group Education terhadap Kemampuan Bystander CPR
}

\author{
Nove Lestari, Vela Purnamasari \\ STIKES Karya Husada Kediri, Prodi D3 Keperawatan, Jl. Soekarno Hatta No.7, \\ Darungan, Kec. Pare, Kediri, Jawa Timur \\ Email: nophetari@yahoo.com \\ $\begin{array}{ll}\text { Diterima } & : 3 \text { November } 2020 \\ \text { Disetujui } & : 26 \text { November 2020 } \\ \text { Dipublikasikan } & : 10 \text { Desember 2020 }\end{array}$
}

\begin{abstract}
Abstrak
Latar Belakang dan Tujuan: Kejadian henti jantung ditandai dengan tidak adanya tanda - tanda sirkulasi seringkali ditemukan terjadi diluar rumah sakit yang membutuhkan pertolongan pertama dari orang - orang yang berada di sekitar korban (Bystander). Community Education System (CUBES) dengan pendekatan Peer Group Education merupakan pemberian pendidikan kesehatan yang diberikan sasaran dengan jumlah yang banyak dengan karakteristik sasaran yang hampir sama, yang dilaksanakan secara kontinue dan dalam periode tertentu yang dalam rentang waktu yang telah direncanakan tersebut ada evaluasi hasil secara berkala. Tujuan penelitian ini untuk mengetahui adanya efektifitas Cubes dengan pendekatan peer grup education terhadap kemampuan bystander CPR.

Metode: Metode penelitian yang digunakan quasy eksperiment melalui pendekatan Pre dan Post Test Without Control dengan teknik Non Probability Sampling tipe Purposive Sampling dengan populasi 41 orang dan didapatkan sejumlah 8 responden.

Hasil: Dari hasil uji T-Test berpasangan tersebut didapatkan hasil Significancy 0,000 dimana nilai p-value $<0,05$.

Simpulan dan Implikasi: Terdapat perbedaan rerata kemampuan responden dalam melakukan CPR yang bermakna sebelum dan sesudah dilakukan intervensi Community Education System (CUBES) dengan pendekatan Peer Group. Diharapkan masyarakat selaku bystander CPR lebih berinsiatif serta berperan serta dalam pemberian bantuan hidup dasar kepada pasien henti jantung sehingga komplikasi bisa diminimalisir.
\end{abstract}

Kata Kunci: Bystander CPR; Community Education System; Kemampuan, Peer group

Sitasi: Lestari N \& Purnamasari V. (2020). Efektifitas community education system (CUBES) dengan pendekatan peer group education terhadap kemampuan bystander CPR. The Indonesian Journal of Health Science. 12(2), 183-192

Copyright: (C) 2020 Lestari et. al. This is an open-access article distributed under the terms of the Creative Commons Attribution-NonCommercial 4.0 International License, which permits unrestricted use, distribution, and reproduction in any medium, provided the original author and source are credited.

Diterbitkan Oleh: Universitas Muhammadiyah Jember

ISSN (Print): 2087-5053

ISSN (Online): 2476-9614 


\begin{abstract}
Background and Aim: The incidence of cardiac arrest characterized by the absence of signs of circulation is often found to occur outside the hospital requiring first aid from people around the victim (Bystander). Community Education System (CUBES) with the Peer Group Education approach is the provision of health education that is given a large number of targets with almost the same characteristics, which is carried out continuously and in a certain period within the planned time frame that there is periodic evaluation of results. The purpose of this study was to determine the effectiveness of Cubes with a peer group education approach on the ability of CPR bystander.

Methods: The research method used was quasy experiment through the Pre and Post Test Without Control approach with the Non Probability Sampling type purposive sampling technique with a population of 41 people and obtained a number of 8 respondents.

Results: From the results of the Paired T-Test, the Sig-nificancy results of 0,000 were obtained where the p-value was <0.05.

Conclusion: There was a significant difference in the mean ability of respondents to perform CPR before and after the Community Education System (CUBES) intervention was carried out with Peer Group approach. It is hoped that the community as the CPR bystander will be more innovative and participate in providing basic life support to cardiac arrest patients so that complications can be minimized.
\end{abstract}

Keywords: Ability; Bystander CPR; Community Education System; Peer group

\section{PENDAHULUAN}

Cardiac arrest adalah hilangnya fungsi jantung secara tibatiba dan mendadak, bisa terjadi pada seseorang yang memang didiagnosa dengan penyakit jantung ataupun tidak. Waktu kejadiannya tidak bisa diperkirakan, terjadi dengan sangat cepat begitu gejala dan tanda tampak (American Heart Association, 2010). Gambaran klinis dari henti jantung ini adalah kehilangan kesadaran mendadak, tidak adanya denyut karotis atau femoralis, henti napas segera timbul sesudahnya. Menurut data WHO menyebutkan bahwa serangan jantung masih menjadi pembunuh manusia nomor satu di negara maju dan berkembang dengan menyumbang 60 persen dari seluruh kematian. Henti jantung menjadi penyebab utama kematian di beberapa Negara dan terjadi baik di luar rumah sakit maupun di dalam rumah sakit. Out of hospital cardiac arrest atau yang disebut dengan OHCA merupakan kejadian henti jantung yang ditandai dengan tidak adanya tanda - tanda sirkulasi dan terjadi diluar rumah sakit.

Menurut Gordon and Sanders dalam artikel jurnal yang dipublikasikan dalam Journal of The American College of Cardiology tahun 2013, di Amerika Serikat terjadi sekitar 360.000 kasus cardiac arrest di luar rumah sakit, dimana hal tersebut merupakan $15 \%$ dari penyebab seluruh kematian dan setiap tahun sekitar 310.000 orang mengalami Sudden Cardiac Arrest (SCA) dan ini terjadi di dalam maupun di luar rumah sakit, dan 
angka kejadian meninggal sebelum tiba di rumah sakit mencapai $95 \%$. Di Indonesia angka kejadian Cardiac Arrest belum bisa dipastikan jumlah kejadiannya, karena sebagian besar korban yang mengalami henti jantung ini dibiarkan begitu saja tanpa ada usaha pertolongan dari orang-orang disekitar korban (bystander) dan minimal sekali inisiatif bystander untuk membawa korban ke sarana pelayanan kesehatan terdekat yang disebabkan karena minimnya pengetahuan serta ketrampilan dari bystander dalam melakukan Cardiopulmonary Resuscitation $(C P R)$ sebagai upaya pelaksanaan bantuan hidup dasar pada korban cardiac arrest.

Hal ini menunjukkan bahwa orang - orang yang ada di sekitar korban (bystander) mempunyai peranan yang sangat penting dalam meningkatkan keberlangsungan hidup pasien dengan henti jantung (Shah, et,all 2013). Kebedaan dan jumlah masyarakat yang memberikan pertolongan RJP ketika menemukan korban dengan henti jantung yang terjadi secara mendadak masih tergolong rendah dan bervariasi dengan tingkat terendah $1 \%$ dan tertinggi yaitu sekitar 44\% (Bohan, 2010). Beberapa hal yang menyebabkan rendahnya jumlah masyarakat yang memberikan bantuan hidup dasar kepada korban dengan henti jantung mendadak dikarenakan rendahnya kemampuan secara intelektual serta rendahnya kepedulian masyarakat untuk melakukan CPR (Pallin, 2013).

Penatalaksanaan pada sudden cardiac arrest adalah dengan menggunakan prinsip chains of survival. Chains of survival dimulai dari mengenal korban yang mengalami henti jantung, segera menghubungi ambulans (early acces), melakukan CPR (early CPR), memberikan defibrilasi secepat mungkin (early defibrillation), memberikan bantuan hidup lanjut yang efektif dan memberikan perawatan pasca henti jantung yang terintegrasi (early advance care) (Nolan, 2010). Karena inti dari penanganan pada sudden cardiac arrest adalah kemampuan untuk mendeteksi dan bereaksi secara cepat dan benar untuk mengembalikan denyut jantung kembali pada keadaan normal sehingga mencegah kematian dan cacat permanen. Akan tetapi hal ini bukanlah sesuatu yang mudah untuk dilakukan, menurut Travers et al (2014), masyarakat pada umumnya kurang mampu untuk mendeteksi dengan cepat adanya cardiac arrest ketika menemukan korban tidak sadar. Mereka akan mengaktifkan EMS atau memanggil ambulans, tetapi kemudian tidak langsung melakukan CPR. Hal ini yang akan membuat tingkat keberhasilan penanganan cardiac arrest tetap rendah. Pemberian CPR oleh penolong yang pertama kali dapat meningkatkan survival rate pasien.

Menurut Lai et al (2014), sejumlah penelitian sekarang mengkonfirmasi kesempatan terbaik untuk bertahan hidup tergantung pada faktor yaitu bystander CPR(cardiopulmonary resuscitation) dan kualitas CPR yang dilakukan oleh bystander. Bystander CPR dapat meningkatkan kelangsungan hidup para korban apabila cepat terdeteksi dan dilakukan tindakan CPR yang tepat sesuai dengan standar. Penelitian lain tim dari Cares Surveillance Group, dipublikasikan dalam The New Eng- 
land Journal of Medicine, hasil penelitian ini menunjukan bahwa karakteristik bystander sangat mempengaruhi inisiatif untuk memberikan pertolongan, terlebih lagi pada bystander dengan tingkat pendidikan yang rendah merasa takut untuk mengambil keputusan apa yang harus dilakukan serta pertolongan seperti apa yang tepat saat menghadapi korban Cardiac Arrest. Karakteristik bystander yang berada disekitar korban pada saat kejadian Cardiac Arrest sangat mempengaruhi inisiatif bystander untuk memberikan pertolongan segera pada korban.

Edukasi serta pelatihan terkait penanganan pada kasus Cardiac Arrest terutama yang terjadi diluar rumah sakit merupakan hal yang sangat penting untuk diberikan serta disosialisasikan kepada masyarakat sebagai upaya meningkatkan jumlah bystander CPR di Indonesia khususnya di Kabupaten Kediri. Upaya pemberian edukasi ini dapat dilakukan dengan menggunakan Community Education System (CUBES) dengan pendekatan Peer Group Education yang penerapannya dapat dilakukan pada sasaran dengan jumlah yang banyak dengan karakteristik sasaran yang hampir sama. Community Education System (CUBES) dengan pendekatan Peer Group Education ini merupakan pemberian informasi kesehatan yang dilakukan dengan menggunakan berbagai media pembelajaran (Buku, video, slide show, leaflet) yang dilaksanakan secara kontinue dan dalam periode tertentu yang dalam rentang waktu yang telah direncanakan tersebut ada evaluasi hasil secara berkala, sehingga akan dapat dilakukan pengukuran secara valid akan tingkat keberhasilan dari Community Education System (CUBES) dengan pendekatan Peer Group Education ini.

Dari permasalah diatas dapat kita analisis bahwa pendidikan tentang pertolongan pertama Sudden Cardiac Arrest (SCA) bagi bystander sangatlah penting untuk membantu mengurangi angka kematian akibat $S C A$. Di Indonesia, kemampuan bystander untuk mengenali tanda henti jantung masih sangat kurang dan masyarakat juga kesulitan untuk mendapatkan akses pelayanan gawat darurat yang cepat pada saat dibutuhkan. Sehingga bystander ini cenderung tidak berani mengambil keputusan apa yang harus dilakukan jika mengetahui adanya korban yang tergeletak di dekatnya. Untuk itu perlu sekali pendidikan tentang pertolongan bantuan hidup dasar yang diberikan pada masyarakat awam, khususnya di fasilitas layanan publik atau di setiap rumah yang berpotensi terjadi Cardiac Arrest. Untuk itu penulis mencoba untuk memberikan alternatif pembelajaran pemberian bantuan hidup dasar pada masyarakat awam yang mungkin bisa diterapkan di Indonesia, dengan Community Education System (CUBES) dengan pendekatan Peer Group Education sebagai upaya peningkatan jumlah bystander CPR di Desa Pelem Kecamatan Pare Kabupaten Kediri.

\section{METODE PENELITIAN}

Penelitian dilaksanakan di Desa Pelem, Kec. Pare, Kab. Kediri dalam waktu 8 minggu dengan desain quasy eksperiment melalui pendekatan Pre dan Post test without control. Populasi pada penelitian ini 
adalah seluruh kader yang tinggal Desa Pelem sejumlah 41 orang. Sampel dalam penelitian ini adalah sebagian yang memenuhi kriteria inklusi yaitu sejumlah 8 responden. Teknik sampling yang digunakan adalah Non Probability Sampling tipe Purposive Sampling. Tehnik analisa data yang digunakan dalam penelitian ini adalah Paired $t$ test (menganalisis tingkat kemampuan bystander CPR Pre dan Post test pada kelompok perlakuan).

\section{HASIL}

Penelitian ini dilakukan di Desa Pelem Kecamatan Pare Kabupaten Kediri dengan responden KADER Di Desa Pelem yang kooperatif dan bersedia menjadi responden. Populasi sampel penelitian sebanyak 41. Sampel diambil menggunakan rumus besar sampel dan kemudian dipilih menggunakan teknik Purpossive Sampling dengan jumlah sampel yang memenuhi kriteria inklusi sebanyak 8 responden. Penelitian dilakukan dengan memberikan intervensi CUBES (Community Education System) dengan pendekatan Peer Group pada responden yang dilakukan pada bulan Agustus Oktober 2020. Dikarenakan sedang adanya pandemi Covid 19 ini Community Education System (CUBES) ini yang awalnya direncanakan dilaksanakan secara tatap muka intens dengan responden akhirnya harus dilaksanakan dengan teknik kombinasi yaitu $50 \%$ tatap muka dan $50 \%$ secara online (daring). Community Education System (CUBES) 3 kegiatan yang meliputi kegiatan I,II dan III.

Kegiatan pertama setelah dilakukan informed consent pada seluruh responden peneliti mengidentifikasi pengetahuan dan kemampuan responden tentang pemberian CPR pada pasien dengan henti jantung dengan membagikan kuesioner Pre Test. Kegiatan II yaitu responden dibagi menjadi 2 kelompok (peer group), kemudian dilakukan intervensi Community Education System (CUBES) secara kontinue selama $8 \mathrm{x}$ pertemuan (4 pertemuan daring atau online dan $4 \mathrm{x}$ pertemuan tatap muka secara langsung). Kegiatan yang III yaitu melakukan evaluasi kemampuan Post Test seluruh responden yang dilakukan dengan melakukan evaluasi kemampuan responden satu persatu dengan menggunakan lembar observasi penilaian kemampuan CPR. Pengambilan data pretest tentang kemampuan CPR diambil setelah mengisi informed consent dan sebelum kegiatan I dilaksanakan. Sedangkan data posttest kemampuan CPR diambil setelah seluruh intervensi selesai diberikan.

Tabel 1 menjelaskan bahwa responden yang berusia 31-40 yaitu sebesar 50\% usia termuda adalah 24 tahun dan yang paling tua adalah 51 tahun. Dan jenis kelamin adalah perempuan yaitu sejumlah $75 \%$. Tingkat pendidikan responden terbanyak adalah lulusan perguruan tinggi yaitu sejumlah $75 \%$. Seluruh responden berstatus sudah menikah dan sebagian besar yaitu sejumlah $62,5 \%$ tinggal dengan keluarga inti. Setengan dari responden juga menyatakan bahwa pernah mendapatkan informasi tentang CPR yaitu sejumlah $50 \%$.

Berdasarkan hasil uji T-Test berpasangan didapatkan hasil Significancy 0,000. Hasil tersebut menjelaskan bahwa nilai p-value < 0,05 , sehingga dapat disimpulkan 
bahwa terdapat perbedaan rerata intervensi Community Education kemampuan responden dalam melakukan CPR yang bermakna sebelum dan sesudah dilakukan System (CUBES) dengan pendekatan Peer Group (Tabel 2).

Tabel 1. Distribusi Frekuensi Responden Berdasarkan Umur, Jenis Kelamin, Pendidikan, Status Perkawinan, Penghasilan, Tinggal Serumah Dengan dan Pernah Mendapatkan Informasi

\begin{tabular}{llll}
\hline & Kategori & Frekuensi & Persentase (\%) \\
\hline Umur & 20-30 tahun & 2 & 25 \\
& 31-40 tahun & 4 & 50 \\
& 41-50 tahun & 2 & 25 \\
Jenis Kelamin & Laki-Laki & 2 & 25 \\
& Perempuan & 6 & 75 \\
Pendidikan & SMA & 2 & 25 \\
\multirow{5}{*}{ Status Perkawinan } & Menikah & 6 & 75 \\
Penghasilan & $>$ 1 Juta/Bulan & 8 & 100 \\
Tinggal Serumah & Suami/ Istri dan Anak & 5 & 100 \\
Dengan & Suami/ Istri Saja & 1 & 62,5 \\
& Keluarga Besar & 2 & 12,5 \\
& Pernah & 4 & 25 \\
Mendapatkan & Tidak Pernah & 4 & 50 \\
Informasi & & 50 \\
\hline
\end{tabular}

Table 2. Hasil Uji statistik T-Test Berpasangan (Pre-Post test kemampuan bystander $C P R$ )

\begin{tabular}{|c|c|c|c|c|c|c|}
\hline \multirow{2}{*}{$\begin{array}{c}\text { Kemampuan } \\
\text { Bystander } \\
\text { CPR }\end{array}$} & \multirow[b]{2}{*}{ Mean } & \multirow{2}{*}{$\begin{array}{l}\text { Standar } \\
\text { Deviasi }\end{array}$} & \multirow{2}{*}{$\begin{array}{c}\text { Standar } \\
\text { Error } \\
\text { Mean }\end{array}$} & \multicolumn{2}{|c|}{$95 \% \mathrm{CI}$} & \multirow[b]{2}{*}{ P Value } \\
\hline & & & & Min & Maks & \\
\hline $\begin{array}{l}\text { Sebelum dan } \\
\text { Sesudah }\end{array}$ & 15,000 & 2,507 & 0,886 & $-17,096$ & $-12,904$ & 0,000 \\
\hline
\end{tabular}

\section{PEMBAHASAN}

Community Education System
merupakan suatu sistem
pembelajaran dan pemberian
pendidikan kepada masyarakat luas
(komunitas) sehingga pendidikan
menjadi usaha kolaboratif yang
melibatkan partisipasi masyarakat di

dalamnya. Kemunculan paradigma pendidikan berbasis komunitas dipicu oleh arus besar modernisasi yang menghendaki terciptanya demokratisasi dalam segala kehidupan manusia, termasuk dalam bidang pendidikan (Hardiyanti, 2018). Pemberian pendidikan kesehatan kepada masyarakat awam 
akan sangat penting mengingat keberadaan masyarakat merupakan bagian dari individu - individu yang tidak dapat dipisahkan. Seringkali di temukan situasi gawat darurat yang terjadi ditengah - tengah masyarakat seperti kasus henti jantung mendadak (cardiac arrest). Di Indonesia angka kejadian Cardiac Arrest belum bisa dipastikan jumlah kejadiannya, karena sebagian besar korban yang mengalami henti jantung ini dibiarkan begitu saja tanpa ada usaha pertolongan dari orang-orang disekitar korban (bystander) dan minimal sekali inisiatif bystander untuk membawa korban ke sarana pelayanan kesehatan terdekat yang disebabkan karena minimnya pengetahuan serta ketrampilan dari bystander dalam melakukan Cardiopulmonary Resuscitation $(C P R)$ sebagai upaya pelaksanaan bantuan hidup dasar pada korban cardiac arrest. Hal ini membutuhkan upaya pertolongan pertama oleh masyarakat awam (bystander) untuk menyelamatkan nyawa korban henti jantung.

Dalam pemberian intervensi Community Education System (CUBES) dengan pendekatan Peer Group ini akan mempermudah masyarakat awam atau by stander yang dalam hal ini adalah Kader dalam menerima informasi yang diberikan selama proses pemberian intervensi karena mereka terbagi menjadi kelompok - kelompok kecil yaitu sejumlah 4 orang dalam masing - masing kelompoknya yang mempunyai karakteristik yang hampir sama sehingga mereka akan merasa nyaman selama proses interaksi berlangsung. Pemberian intervensi CUBES ini dilaksanakan kontinue dengan metode tatap muka langsung dan secara online (daring) via Whatsap Group dikarenakan selama penelitian berlangsung masih dalam situasi pandemi Covid 19.

Pemberian pendidikan

kesehatan berbasis komunitas bukanlah suatu hal sederhana yang bisa dengan mudah karena membutuhkan kerjasama dari berbagai lini di dalam masyarakat tersebut. Peran serta dari masyarakat sangatlah penting guna merencananakan, mengelola dan menilai sendiri apa yang diperlukan secara spesifik dari dan untuk masyarakat itu sendiri (Hardiyanti, 2018). Masyarakat yang kemudian dikelompokkan menjadi kelompok kelompok kecil yang mempunyai karakteristik yang sama akan dapat mempermudah terjadinya interaksi dalam kelompoknya. Dalam kelompok sebaya, pada masing masing anggotanya akan terjalin hubungan yang erat dan bersifat pribadi (Susan, 2011). Peer group support adalah dukungan yang diberikan dari sekelompok orang yang merasa memiliki beberapa kesamaan baik dari segi usia, pola pikir, minat, atau hal yang lain kepada orang yang mengaku atau mempunyai hal serupa. Pendidikan kesehatan yang diberikan secara kontinue akan dapat meningkatkan pengetahuan serta kemampuan individu. Masyarakat awam yang dalam hal ini adalah selaku (bystander) CPR memerlukan pemberian pendidikan kesehatan guna meningkatkan pengetahuan serta kemampuan mereka dalam melakukan CPR sebagai upaya pemberian bantuan hidup dasar kepada pasien dengan Cardiac Arrest.

Berdasarkan hasil peneliatian Menjelaskan bahwa dari hasil uji T-Test Berpasangan tersebut didapatkan hasil Significancy 0,000. Hasil tersebut 
menjelaskan bahwa nilai $\mathrm{p}$-value $<0,05$, dengan batas nilai bawahnya adalah sebesar -17,096 serta batas nilai tertinggi adalah sebesar -12,096 sehingga dapat disimpulkan bahwa terdapat perbedaan rerata kemampuan responden dalam melakukan CPR yang bermakna sebelum dan sesudah dilakukan intervensi Community Education System (CUBES) dengan pendekatan Peer Group. Hal ini dipengaruhi oleh tingkat pendidikan responden yang sebagian besar yaitu sejumlah $75 \%$ merupakan lulusan perguruan tinggi, sebagian dari responden yaitu sejumlah 50\% responden pernah mendapatkan informasi tentang bantuan hidup dasar serta pemberian Community Education System yang dilakukan secara periodik dan kontinue.

Menurut Lai et al (2014), sejumlah penelitian sekarang mengkonfirmasi kesempatan terbaik untuk bertahan hidup tergantung pada faktor yaitu bystander CPR (cardiopulmonary resuscitation) dan kualitas CPR yang dilakukan oleh bystander. Bystander CPR dapat meningkatkan kelangsungan hidup para korban apabila cepat terdeteksi dan dilakukan tindakan CPR yang tepat sesuai dengan standar. Pengetahuan dan kemampuan responden dalam melakukan bantuan hidup dasar sangat dipengaruhi juga oleh tingkat pendidikan responden. Kader yang dinamis dengan pendidikan rata - rata tingkat desa ternyata akan dapat mampu melaksanakan beberapa kegiatan yang sederhana tetapi tetap berguna bagi masyarakat di kelompoknya (effendi dan Makhfudi, 2009). Tingkat pendidikan yang tinggi diharapkan responden akan lebih mudah menerima serta mengaplikasikan informasi yang telah diberikan (Hamalik dan Oemar, 2013).
Peran serta dari masyarakat sangatlah penting guna merencananakan, mengelola dan menilai sendiri apa yang diperlukan secara spesifik dari dan untuk masyarakat itu sendiri (Hardiyanti, 2018). Pemberian pendidikan kesehatan yang dilakukan secara kontinue dan periodik akan dapat meningkatkan pengetahuan serta kemampuan masyarakat awam (bystander) dalam melakukan CPR sebagai upaya pemberian bantuan hidup dasar. Keikutsertaan masyarakat dalam meningkatkan efisiensi pelayanan adalah atas dasar pemikiran bahwa terbatasnya daya dan dana dalam operasional pelayanan kesehatan akan mendorong masyarakat memanfaatkan sumber daya yang ada seoptimal mungkin. Edukasi serta pelatihan terkait penanganan pada kasus Cardiac Arrest terutama yang terjadi diluar rumah sakit atau di tengah - tengah masyarakat merupakan hal yang sangat penting untuk diberikan serta disosialisasikan kepada masyarakat selaku bystander CPR sebagai upaya pemberian bantuan hidup dasar.

\section{SIMPULAN}

Adanya inisiatif untuk memberikan pertolongan pertama dari orang - orang yang ada di sekitar korban (bystander) mempunyai peranan yang sangat penting dalam meningkatkan keberlangsungan hidup pasien dengan henti jantung. Pemberian Community Educational System (Cubes) dengan pendekatan peer group yang dilakukan secara kontinue dan periodik akan dapat meningkatkan pengetahuan serta kemampuan masyarakat awam (bystander) dalam melakukan CPR sebagai upaya pemberian bantuan 
hidup dasar, sehingga komplikasi lebih lanjut dari kondisi henti jantung tersebut dapat diminimalisir.

\section{SARAN}

Edukasi serta pelatihan terkait penanganan pada kasus Cardiac Arrest terutama yang terjadi diluar rumah sakit atau di tengah tengah masyarakat merupakan hal yang sangat penting untuk diberikan serta disosialisasikan kepada masyarakat selaku bystander CPR sebagai upaya pemberian bantuan hidup dasar. Pemberian edukasi ini bisa terlaksana baik dengan adanya kerjasama antara pihak Puskesmas dengan pemerintahan Desa terkait sehingga bystander CPR akan lebih siap dalam memberikan pertolongan pertama saat menemukan pasien dengan henti jantung.

\section{DAFTAR PUSTAKA}

Anoop S.V. Shah, K. S. V. S., Raj Bhopal, Comilla Sasson, David J. Magid, Jason S. Haukoos. (2013). Neighborhood characteristics and bystanderinitiated CPR. The New England Journal of Medicine, 368(4), 391-392.

Bair, A. E. (2008). AHA call to action: Compression-only CPR. Journal Watch Emergency Medicine.

Bohan, J. S. (2000). Bystander CPR by chest compression alone. Journal Watch. Emergency Medicine.

Bohan, J. S. (2010). Bystander cardiopulmonary resuscitation: Chest compression alone or with rescue breathing?. Journal Watch. Emergency Medi- cine.

Florence Dumas, L. W., Benjamin A. Stubbs, Alain Cariou, Thomas D. Rea. (2012). Long-term prognosis following resuscitation from out of hospital cardiac arrest. Journal of American College of Cardiology, 60(1), 21-27.

Gordon A Ewy, A. B. S. (2013). Alternative approach to improving survival of patients with out-of-hospital primary cardiac arrest. Journal of American College of Cardiology, 16(2), 113-118.

Greco, P., Pendley, J.S., McDonell, K., Reeves, G., 2001. A peer group intervention for adolescents with type 1 diabetes and their best friends, Journal of Pediatric Psychology. vol.26 no.8 hal.485-490. doi: 10.1093/jpepsy/26.8.485 diakses dari http://jpepsy.oxfordjournals.o $\mathrm{rg} / \mathrm{cont}$ ent/26/8/485.

Hamalik dan Oemar. (2013). Proses belajar mengajar. Jakarta : PT Bumi Aksara

Heisler, M., 2007. Overview of peer support models to improve diabetes self management and clinical outcomes, Diabetes Spectrum, vol.20 no.4 hal.214-221diakses dari http://spectrum.diabetesjour nals.org/ content/20/4/214.

Ilkafah, 2011. Thesis: pengaruh peer group support terhadap self efficacy kontol gula darah dan self care activities pada penderita diabetes mellitus di Puskesmas Mantup $\mathrm{Ka}$ bupaten Lamongan. Surabaya: Fakultas Keperawatan UNAIR. 
Jerry P Nolan, J. S. (2010). Dispatcher-assisted bystander CPR: A kiss for a kiss. The Lancet, 376(9752), 15221524.

Kelana, D, S. (2011). Metodologi penelitian keperawatan. Jakarta. : CV Trans Info Media

Koenig, K. L. (2013). Dispatcher assistance improves bystander CPR rates. Journal Watch Emergency Medicine.

Nursalam. (2014). Konsep dan penerapan metodelogi penelitian ilmu keperawatan. Jakarta : Salemba Medika

Nursalam. (2017). Metodologi penelitian ilmu keperawatan : Pendekatan praktis Edisi 4. Jakarta : Salemba Medika

Pallin, D. J. (2013). Increased bystander CPR and better survival in denmark. NEJM Journal Watch. Emergency
Medicine.

Rakan S Al-Rasheed, J. D., Jennifer A Dunbar-Viveiros, Mark S Jones, Max Dannecker, Gregory D Jay, Leo Kobayashi. (2013). Development of simulated chest compression videos for objective evaluation of CPR instructors. The Journal of Continuing Education in Nursing, 44(2), 59-63.

Sugiyono. 2015. Metode penelitian pendidikan : pendekatan kuantitatif, kualitatif, dan $R \& D$. Bandung : Alfabeta

Travers, S., Jost, D., Gillard, V., Lanoe, V., Bignand, M., Domanski, L., and Tourtier, J.P., (2014). Out-of-hospital cardiac arrest phone detection: those who most need chest compressions are the most difficult to recognize. Elsevier Ireland Ltd. 